\title{
Physical Exercise To Recovery of Consciousness in Post Operative Patients With General Anesthesia
}

\author{
Hapipah, Erida Apsarina, Istianah \\ STIKES YARSI Mataram NTB, Indonesia \\ *pey.hapipah15@gmail.com
}

\begin{abstract}
Surgery is a surgical procedure that in the implementation is very risky. General anesthesia is one of the techniques that is often chosen in performing surgery as a painkiller when going through surgery, followed by loss of consciousness. Early post-surgery there may be aspiration and decreased ventilation. Therefore to accelerate the recovery of post general anesthesia efforts are with preoperative physical exercises i.e. deep breath exercises, effective coughs, and range of motion. This study aims to find out the effect of physical exercise on the recovery of consciousness of post operative patients with general anesthesia. The type of research used in this study is Pre experimental with one shot case study design. The sample in this study was 20 respondents. The technique used to collect samples is purposive sampling technique. Instruments in this study used Aldrete score. The data was analyzed using Univariate and Bivariate analysis. The data analysis showed an average difference in the aldrete score scoring of the control group and the intervention group (4), (4), (6.1), (7.8), (8.3), (9.3) and (4), (6), (9.3), (9.9), (9.9), (10). The results of the data analysis using the Mann Whitney test showed a signification value of $0.000 \mathrm{p}$ value $<0.05$ ), which means there was a difference in consciousness recovery between the group given physical exercise (intervention) and not given physical exercise (control). Based on this research, it is hoped that physical exercise can be applied as an action to help the recovery of consciousness of post operative patients with general anesthesia in the recovery room.
\end{abstract}

Keywords: Physical Exercise, Recovery of Consciousness, General Anesthesia 


\section{STRADA Jurnal Ilmiah Kesehatan}

DOI: $10.30994 /$ sjik.v9i2.456

ISSN: 2252-3847 (print); 2614-350X (online)

Vol.9 No.2 November 2020 Page.1223-1229

\section{BACKGROUND}

Surgery is a surgical procedure that in the implementation is very risky, causing the patient's condition during surgery to be weak, increasing complications after the operation is performed and can lead to death (Pearse \& Moreno, 2012). After surgery the patient can experience surgical area pain, cough and a lot of mucus in the throat (Smeltzer \& Bare, 2013). Based on data obtained from the World Health Organization (WHO) in 2013 the number of patients with surgery achieved a very significant increase from year to year. Recorded in 2011 there were 140 million patients in all hospitals in the world, while in 2012 the data increased by 148 million people, while for Indonesia in 2012 reached 1.2 million people (Sartika, 2013). The prevalence of surgery incidents in West Nusa Tenggara from 2011 to 2014 increased from 2.3\% to 9.3\% (Dikes NTB, 2015). While in Mataram Public Hospital the number of patients performed surgery from 2012 to 2015 the number in a row was 526, 608, 725, and 882 patients. Of these patients the most surgery is major surgery using general anesthesia. The number of patients given general anesthesia at Mataram Public Hospital from January to April 2018 was 224, 248, 251, and 260 patients (Mataram Public Hospital Medical Record, 2018).

In each surgery, an effort is required to relieve pain using anesthesia consisting of two general anesthesia and regional anesthesia. General anesthesia is the most commonly chosen technique in performing surgery as one of the painkillers when going through surgery, followed by loss of consciousness (Keat Et al, 2013). Post-surgery, recovering from general anesthesia is routinely managed in the recovery room. Recovery room (RR) or conscious recovery room is a room located near the operating room, close to the surgical nurse, anesthesiologist and surgeon, so that in the event of a postoperative emergency, the client can be immediately given assistance. As long as it is not fully aware, the client is left to stay in the recovery room (Kozier \& Erb, 2010).

Patients with airway and ventilation disorders should be treated early. In addition to airway obstruction due to back-to-back tongue or laryngeal spasm, early postoperative nausea may result in aspiration, deep anesthesia, and residual effects of muscle paralysis will result in decreased ventilation. Therefore to accelerate the recovery of post general anesthesia efforts made among others with preoperative physical exercise, this is important as the preparation of patients in the face of postoperative conditions, such as: surgical area pain, cough and a lot of mucus in the throat due to the effect of general anesthesia procedures (Smeltzer \& Bare, 2013).

Patients or families of patients often have the wrong view of the patient's movements after surgery, many patients do not want to move the body for fear of stitches torn surgery or fear of the wounds of the operation is long healed. This view is clearly wrong because precisely if the patient finishes surgery and moves immediately then the patient will more quickly stimulate the peristaltic intestine so that the patient will flatus faster, which means that the function of digestion returns faster and will certainly also affect the patient's consciousness (Renggonowati, 2014). Nurses as health workers should give education to patients and families of patients about surgery and what to do before and after surgery. Before surgery the nurse will provide informed consent and provide physical training to the patient in preparation for postoperative conditions. This aims that after the patient has finished surgery and is in the recovery room the patient can do the physical exercises that have been taught by the nurse, so as to help the patient in the recovery of consciousness (Sudiono, 2014).

Physical exercises given to patients before surgery include: deep breath exercises, this exercise is very beneficial for patients to reduce pain after surgery and can help 


\section{STRADA Jurnal Ilmiah Kesehatan}

DOI: $10.30994 /$ sjik.v9i2.456

ISSN: 2252-3847 (print); 2614-350X (online)

Vol.9 No.2 November 2020 Page.1223-1229

patients relax so that patients are better able to adapt to pain and can improve sleep quality. In addition, this technique can also improve pulmonary ventilation and blood oxygenation after general anesthesia. Patients who have become aware are expected to practice deep breathing exercises effectively and correctly according to the patient's condition and needs, effective cough exercises, necessary for clients who undergo surgery under general anesthesia, due to the installation of breathing apparatus during anesthesia so that when aware of the patient will experience discomfort in the throat, a lot of viscous mucus (Smeltzer \& Bare, 2013).

Preliminary study at Mataram Public Hospital at Recovery Room through an interview with one of the surgical nurses said that the number of patients who received general anesthesia for one month averaged 250 patients and no physical exercise measures were given to pre and post surgery patients, which was done only observing vital signs and awareness based on alderete score. Through the interview, data was also obtained that the patient's recovery time in mataram public hospital recovery room is 1-2 hours after it has just been transferred to the inpatient room. Setyono's 2014 study said that more patients were conscious less than an hour after being given lower extremity passive exercises so that an action was needed to accelerate the recovery of patient awareness, one of which is with physical exercise.

Based on the description, this research was conducted to analyze the difference between patients who are given physical exercise and not given physical exercise to the recovery time of consciousness of post operative patients with general anesthesia in the recovery room of Mataram Public Hospital.

\section{METHODS}

This study was a quasi experiment with postest design only with control group design which is to compare two groups between those who have been treated and not given treatment. The first and second groups were both observed awareness post surgery, then the first group was given physical exercise while the second group was not given physical exercise. After being given the treatment was observed again the consciousness. This research was conducted in September 2019 in the Recovery room of Mataram Public Hospital. The number of samples used by 20 respondents was divided into 2 groups, intervention group and control group. The technique of sampling with purposive sampling. The research instrument used is the Aldrete Score. Analysis of data on this study using Mann Whitney.

\section{RESULTS}

\section{General Characteristics}

Table 1 Distribution of respondents' general characteristics in control group and intervention group of patients post-operative with General Anesthesia at Mataram Public Hospital in 2019

\begin{tabular}{ccccc} 
No. $\quad$ Characteristics & Control & Intervention & $\mathbf{N}$ & \% \\
\hline Gender & & & & \\
\hline Male & 5 & 3 & 8 & 40 \\
\hline Female & 5 & 7 & 12 & 60 \\
\hline Total & 10 & 10 & 20 & 100 \\
\hline
\end{tabular}


STRADA Jurnal Ilmiah Kesehatan

DOI: $10.30994 /$ sjik.v9i2.456

ISSN: 2252-3847 (print); 2614-350X (online)

Vol.9 No.2 November 2020 Page.1223-1229

\begin{tabular}{ccccc}
\hline \multicolumn{1}{l}{ Age } & & & & \\
\hline $17-25$ & 3 & 3 & 6 & 30 \\
\hline $26-35$ & 1 & 2 & 3 & 15 \\
\hline $36-45$ & 3 & 2 & 5 & 25 \\
\hline $46-55$ & 1 & 0 & 1 & 5 \\
\hline $56-65$ & 0 & 2 & 2 & 10 \\
\hline $66-75$ & 2 & 1 & 3 & 15 \\
\hline $17-25$ & 3 & 3 & 6 & 30 \\
\hline Total & 10 & 10 & 20 & 100 \\
\hline
\end{tabular}

Table 1 shows that the most respondents by gender are 12 women $(60 \%)$ while the male gender was $8(40 \%)$, while the most respondents by age were 17-25 years old as many as 6 people $(30 \%)$ and at least $46-55$ years old as many as 1 person $(5 \%)$.

Table 2 Average results of aldrete score of post operative patients with general anesthesia in the control group at Mataram Public Hospital 2019

\begin{tabular}{lccccc}
\hline \multicolumn{1}{c}{ Variabel } & Mean & Median & $\begin{array}{c}\text { Standar } \\
\text { Deviasi }\end{array}$ & Min & Max \\
\hline Aldrete score $1^{\text {st }} 5$ minutes & 4 & 4 & 0,0 & 4 & 4 \\
\hline Aldrete score $2^{\text {nd }} 5$ minutes & 4 & 4 & 0,0 & 4 & 4 \\
\hline Aldrete score $3{ }^{\text {rd }} 5$ minutes & 6,1 & 6,5 & 1,1 & 4 & 7 \\
\hline Aldrete score $4{ }^{\text {th }} 5$ minutes & 7,8 & 8 & 0,7 & 6 & 9 \\
\hline Aldrete score $5^{\text {th }} 5$ minutes & 8,3 & 8 & 0,6 & 8 & 10 \\
\hline Aldrete score 6 6 th 5 minutes & 9,3 & 9,5 & 0,8 & 8 & 10 \\
\hline
\end{tabular}

Based on the table showed the average aldrete score in the control group in the first 5 minutes to the sixth 5 minutes in a row are (4), (4), (6.1), (7.8), (8.3), (9.3).

Table 3 Average results of aldrete score of post operative patients with general anesthesia in the intervention group at Mataram Public Hospital 2019

\begin{tabular}{lccccc}
\hline \multicolumn{1}{c}{ Variabel } & Mean & Median & $\begin{array}{c}\text { Standar } \\
\text { Deviasi }\end{array}$ & Min & Max \\
\hline Aldrete score $1^{\text {st }} 5$ minutes & 4 & 4 & 0,0 & 4 & 4 \\
\hline Aldrete score $2^{\text {nd }} 5$ minutes & 6 & 6 & 0,9 & 5 & 8 \\
\hline Aldrete score $3{ }^{\text {rd }} 5$ minutes & 9,3 & 9,5 & 0,8 & 8 & 10 \\
\hline Aldrete score $4{ }^{\text {th }} 5$ minutes & 9,9 & 10 & 0,3 & 9 & 10 \\
\hline Aldrete score $5^{\text {th }} 5$ minutes & 9,9 & 10 & 0,3 & 9 & 10 \\
\hline Aldrete score 6 6 th 5 minutes & 10 & 10 & 0,0 & 10 & 10 \\
\hline
\end{tabular}

Based on the table showed the average aldrete score in the intervention group in the first 5 minutes to 5 minutes the sixth experienced an increase from the control group with successive values being (4), (6), (9,3), (9.9), (9.9), (10). 


\section{STRADA Jurnal Ilmiah Kesehatan}

DOI: $10.30994 /$ sjik.v9i2.456

ISSN: 2252-3847 (print); 2614-350X (online)

Vol.9 No.2 November 2020 Page.1223-1229

Effect of physical exercise on recovery of consciousness of post operative patients with general anesthesia

Table 4 The effect of physical exercise on the recovery of consciousness of post operative patients with general anesthesia with mann whitney test

\begin{tabular}{|c|c|c|c|c|c|c|}
\hline & $\begin{array}{l}\text { Aldrete } \\
\text { Score } 1^{\text {st }} \\
5 \\
\text { minutes }\end{array}$ & $\begin{array}{l}\text { Aldrete } \\
\text { Score } \\
2^{\text {nd }} 5 \\
\text { minutes }\end{array}$ & $\begin{array}{l}\text { Aldrete } \\
\text { Score } 3^{\text {rd }} \\
5 \\
\text { minutes }\end{array}$ & $\begin{array}{l}\text { Aldrete } \\
\text { Score } 4^{\text {th }} 5 \\
\text { minutes }\end{array}$ & $\begin{array}{l}\text { Aldrete } \\
\text { Score } 5^{\text {th }} 5 \\
\text { minutes }\end{array}$ & $\begin{array}{l}\text { Aldrete } \\
\text { Score } 6^{\text {th }} 5 \\
\text { minutes }\end{array}$ \\
\hline $\begin{array}{l}\text { Mann-Whitney } \\
\text { U }\end{array}$ & 50,000 & 0,000 & 0,000 & 0,500 & 6,000 & 25,000 \\
\hline Wilcoxon W & 105,000 & 55,000 & 55,000 & 55,500 & 61,000 & 80,000 \\
\hline $\mathbf{Z}$ & 0,000 & $-4,081$ & $-3,853$ & $-4,019$ & $-3,691$ & $-2,492$ \\
\hline P value & 1,000 & 0,000 & 0,000 & 0,000 & 0,000 & $\mathbf{0 , 0 1 3}$ \\
\hline $\begin{array}{l}\text { Exact Sig } \\
{[2 *(1-\text { tailed }} \\
\text { Sig. })]\end{array}$ & 1,000 & 0,000 & 0,000 & 0,000 & 0,000 & 0,063 \\
\hline $\begin{array}{l}\text { Lavene's } \\
\text { Statistic (Sig) }\end{array}$ & 0,000 & 0,014 & 0,449 & 0,101 & 0,081 & 0,000 \\
\hline
\end{tabular}

Based on the table showed the lavene's value on the postoperative aldrete score in the first 5 minutes, the second 5 minutes and the sixth 5 minutes are obtained significant values (0.000), (0.014), and (0.000) where each $\alpha<0.05$ means the control group and the intervention group have the same variant (equal of variances assumed) while at the third 5 minutes, The fourth 5 minutes, and the fifth 5 minutes were scored significantly (0.449), (0.101) and (0.081) which was $\alpha>0.05$ which meant the control group and intervention group had an err variant (equal of variances not asusumed). After statistical tests using the Mann Whitney test, the aldrete score between the control group and the intervention group in the first 5 minutes to the sixth 5 minutes had consecutive signification values of $(1,000)$, (0.000), (0.000), (0.000), (0.000), (0.013). It can be concluded that there was a difference in awareness recovery between the control group and the intervention group in the second 5 minutes, the third 5 minutes, the fourth 5 minutes, the fifth 5 minutes and the sixth 5 minutes. While in the first 5 minutes there was no difference in awareness recovery in both the control group and the intervention group.

\section{DISCUSSION}

From statistical test results with Mann Whitney test obtained significant scores of the first 5 minutes to the sixth consecutive 5 minutes of $(1,000),(0.000),(0.000),(0.000)$, (0.000), (0.013) which means there is an influence on the second 5 minutes, 5 minutes third, 5 minutes fourth, 5 minutes fifth, and 5 minutes sixth, so it can be concluded that there is an effect of physical exercise on the recovery of consciousness of post operative patients with general anesthesia in the recovery room of Mataram Public Hospital in 2019 with a $\mathrm{p}$ value of $<0.05$ except in the first 5 minutes. Things were found during the study where physical exercise had no effect on the first 5 minutes, but in the second 5 minutes, 5 minutes third, 5 minutes fourth, 5 minutes fifth and 5 minutes of sixth physical exercise had an effect on the recovery of consciousness of post operative patients with general anesthesia. 


\section{STRADA Jurnal Ilmiah Kesehatan}

DOI: $10.30994 /$ sjik.v9i2.456

ISSN: 2252-3847 (print); 2614-350X (online)

Vol.9 No.2 November 2020 Page.1223-1229

Postoperative mobilization is a post-surgical activity process starting from light exercises on the bed (breathing exercises, effective cough exercises and moving limbs) that aims to help restore physiological function impaired by anesthesia. Early ambulation exercises can improve blood circulation which will trigger decreased pain and faster wound healing. Exercise therapy and mobilization are the right modalities to restore bodily functions not only to the injured but also to the entire body. Exercise therapy can be passive and active exercise, exercise therapy can also be transfer, positioning and ambulation to increase the ability of self-activity (Smeltzer \& Bare, 2002).

The results of this study were also supported by a study conducted by Sudiono (2014), entitled the effect of physical exercise on the recovery of post-general anesthesia patients in the intensive care installation of Dr. Soedono Madiun hospital where this study said there is an effect of physical exercise on the recovery of post-general anesthesia patients in intensive care installation of hospital dr. Soedono Madiun evidenced by the treatment of physical exercise surgery statistically gives a meaningful influence on the recovery of patients post general anesthesia in the 15th minute post general anesthesia. This is evidenced by the results of aldrete score scoring in the first 15 minutes post-surgery which mostly had a score of 8-10 with the number of 29 respondents $(96.7 \%)$, while those with a score of 5-7 only $(0.3 \%)$ or 1 respondent only, in other words there is an effect of physical exercise surgery on the recovery of patients after general anesthesia. But starting in the 20th, 25th and 30th minutes of physical exercise treatment the surgery did not have a meaningful influence either on the respondent's treatment or on the control respondents.

This is in line with Setyono's research (2014) which said that more patients are conscious less than an hour after being given lower extremity passive exercise so that it is necessary an action to accelerate the recovery of patient awareness one of them is by physical exercise and concluded that there is a effect of passive exercise of lower extremity on the recovery of consciousness in post operative patients with general anesthesia in the conscious recovery room of Slamet Riyadi Army Hospital Surakarta.

According to the researchers in the first 5 minutes there has been no effect of physical exercise on consciousness recovery as evidenced by there has not been an increase in the average aldrete score score between the control group and the intervention group due to the influence of anesthesia that is still deep at the time of completion of the operation. In the second 5 minutes there began to be an increase and then in the 3rd minute there was a very noticeable difference between the control group and the intervention group showed physical exercise began to work in the intervention group, in the fourth and fifth minutes there was still an increase, entering the sixth minute began to decrease the difference but still saw a difference although not as big as in the third 5 minutes because in the last minutes of post surgery the influence of anesthesia had begun to decrease so that physical exercise did not have much effect on the recovery of patient consciousness.

\section{CONCLUTION}

There is an effect of physical exercise to the recovery of consciousness of post operative patients with general anesthesia in the recovery room of Mataram Public Hospital in the second 5 minutes, the third 5 minutes, the fourth 5 minutes, 5 minutes fifth, and 5 th minute sixth with signifkan value $(0.000),(0.000),(0.000(0.000),(0.013)$ ( $\mathrm{p}$ value $<0.05)$. There is no effect of physical exercise on the recovery of consciousness of post operative patients with general anesthesia in the recovery room of Mataram City Hospital in the first 5 minutes with a significant value of 1,000 ( $\mathrm{p}$ value $>0.05$ ). 


\section{STRADA Jurnal Ilmiah Kesehatan}

DOI: $10.30994 /$ sjik.v9i2.456

ISSN: 2252-3847 (print); 2614-350X (online)

Vol.9 No.2 November 2020 Page.1223-1229

\section{REFERENCES}

Dinas Kesehatan Provinsi NTB. (2015). Prevalensi insiden operasi di Nusa Tenggara Barat. Tanggal 28 Juni 2018.

Keat Sally, et al. (2013). Anaesthesia on The Move. Jakarta : Indeks.

Kozier. Erb, Berman. Snyder. (2010). Buku Ajar Fondamental Keperawatan : Konsep, Proses \& Praktik, Volume : 1, Edisi : 7, EGC : Jakarta.

Pearse, R. M., Moreno, R. P., Bauer, P., Pelosi, P., Metnitz, P., Spies, C., Vallet, B., et al. (2012). Mortality after surgery in Europe: a 7 day cohort study. LANCET, 380(9847), 1059-1065.

Phillips, N. M.; Haesler, Emily; Street, Maryann; Kent, Bridie (2011). "Post-anaesthetic discharge scoring criteria: A systematic review". JBI library of systematic reviews. 9 (41): 1679-1713. Diakses tanggal 24 Juli 2018, jam 20.00 WITA.

Renggonowati. (2014). Pengaruh mobilisasi dini terhadap peristaltik usus pasca operasi sesar dengan anestesi spinal di RSUD Tugurejo Semarang. Tanggal 28 Juni 2018.

RM RSUD Kota Mataram, (2018). Data pasien yang melakukan operasi di RSUD Kota Mataram. Tanggal 28 Juli 2018 jam 11.00 WITA.

Setyono, Budi. (2014). Pengaruh Latihan Pasif Extremitas Bawah Terhadap Pemulihan Kesadaran Pada Pasien Post Operasi Dengan Anestesi General Di Ruang Pulih Sadar Rumah Sakit Tentara Slamet Riyadi Surakarta. Jurnal Ilmu Keperawatan Indonesia Vol. 7, No. 2, Juli 2014

Smeltzer \& Bare. (2013). Buku Ajar Keperawatan Medikal Beda Brunner \& Suddarth Edisi 8. Jakarta : EGC.

Sudiono. (2014). Pengaruh latihan fisik terhadap pemulihan pasien pasca general anestesi di instalasi perawatan intensif RSUD dr. Soedono Madiun. Penelitian Program Studi S1 Keperawatan STIKES Pemkab Jombang Program Studi S1 Keperawatan STIKES Pemkab Jombang.

Yunanik. (2014). Pengaruh Rom Exercise Dini Pada Pasien Post Operasi Fraktur Ekstremitas Bawah (Fraktur Femur Dan Fraktur Cruris) Terhadap Lama Hari Rawat Di Ruang Bedah Rsud Gambiran Kota Kediri. Jurnal Ilmu Kesehatan Vol.3 No. 1 Nopember 2014

Rustiawati, Yuni. (2013). Efektivitas Ambulasi Dini terhadap Penurunan Intensitas Nyeri pada Pasien Post Operasi Laparatomi di RSUD Kudus. JIKK Vol. 4, No 2, Juli $2013: 1-8$. 